\title{
PENINGKATAN AKTIVITAS MENGGUNAKAN LABORATORIUM KOMPUTER DAN HASIL BELAJAR SISWA SMK PROGRAM KEAHLIAN AKUNTANSI MELALUI PENERAPAN PROJECT BASED LEARNING
}

\author{
David Firna Setiawan ${ }^{1}$ Aryan Eka Prastya Nugraha ${ }^{2}$ \\ Program Studi Pendidikan Ekonomi Universitas PGRI Semarang \\ davidfirnasetiawan@gmail.com ${ }^{1}$ aryan_eka40@yahoo.com ${ }^{2}$
}

\begin{abstract}
The existence of the computer lab is one thing that is essential to support the improvement of students' competence. Some other researcherssaid that some of the characteristics of PBL and its influence on motivation and learning outcomes, however, these studies can not describe the improvement of the activity in utilizing a computer lab. This study aimed to analyze the differences in the use of computer labs and student learning outcomes at the accounting program to operate accounting computer before and after the implementation of project based learning (PBL). The population of this study was all students of XI class and XII class in accounting programof SMK Al Falah Winong. Sampling in this study is using proportionate stratified random sampling. Data collected through observation. Hypothesis testing is done through t test with two independent samples. The results showed that the application of PBL was able to increase the activity in computer lab and student learning outcomes in the competence particularity on operate computer accounting application.
\end{abstract}

Keywords: Project based learning, computer lab, Student learning outcomes

\section{PENDAHULUAN}

Sekolah menengah kejuruan (SMK) merupakan objek penelitian yang menarik karena SMK merupakan salah satuan pedidikan yang perkembangannya menjadi sorotan pemerintah.Undang-undang Nomor 20 Tahun 2003 Tentang Sistem Pendidikan Nasional menyebut Sekolah Menengah Kejuruan (SMK) merupakan satuan pendidikan formal yang menyelenggarakan pendidikan kejuruan pada jenjang pendidikan menengah.Pendidikan menengah kejuruan mengutamakan pengembangan kemampuan siswa untuk melaksanakan pekerjaan tertentu. Oleh sebab itu,SMK mengajarkan mata pelajaran produktif sesuai dengan bidang keahlian tertentu. Melalui keterampilan tersebut, diharapkan lulusan dari SMK memiliki kesiapan lebih baik dibandingkan dengan sekolah menengah kejuruan (SMK) dalam memasuki dunia kerja.

SMK memiliki berbagai program keahlian yang dapat dipilih siswa pada saat proses penerimaan siswa baru.Program keahlian tersebut dipengaruhi oleh kebutuhan dunia kerja serta kekhasan yang ada diwilayah SMK.Salah satu program keahlian yang ada di SMK adalah program 
keahlian akuntansi. Program keahlian ini ditujukan untuk menyiapkan pesertaa didikuntuk menjadi teknisi akuntansi pelaksana dan penyelia. Persyaratan kelulusan siswa program keahlian akuntansi adalah penguasaan program akuntansi menggunakan software tertentu. Untuk itu, sekolah perlu mengusahakan adanya lingkungan belajar yang relevan. Bentuk lingkungan belajar tersebut adalah adanya laboratorium komputer.

Laboratorium komputer memiliki peranan yang sangat penting dalam menunjang aktivitas pembelajaran berkaitan dengan kompetensi mengoperasikan software akuntansi. Terlebih apabila sebuah SMK berada di daerah pinggiran dimana angka siswa dari kalangan ekonomi kelas menengah kebawah cukup tinggi. Keadaan tersebut menurut Slavin (2005) membawa dampak pada rendahnya hasil belajar disebabkan karena siswa yang berasal dari latar belakang ekonomi menengah kebawah tidak mendapatkan dukungan orang tua terhadap fasilitas belajar seperti yang diperoleh siswa dari golongan ekonomi menengah keatas. Keadaan tersebut merupakan tantangan besar bagi SMK.

Peningkatan kualitas saranaprasarana di lingkungan belajar belum serta merta menyelesaikan permasalahan yang ada. Hal itu disebabkan karena penggunaan sarana-prasarana tersebut masih dipengaruhi oleh motivasi siswa. Karena walaupun sekolah telah mengusahakan peningkatan jumlah komputer dilaboratorium komputer, namun apabila siswa tidak memiliki kemauan untuk menggunakannya secara optimal, maka peningkatan kualitas tersebut tidak akan memberikan dampak yang signifikan terhadap hasil belajar siswa. Oleh sebab itu, dibutuhkan sebuah pemicu agar siswa memiliki kemauan untuk menggunakan laboratorium komputer yang ada disekolah.

Salah satu pemicu yang dapat diberikan adalah melalui pengembangan model pembelajaran project based learning. Pernyataan tersebut didukung dengan hasil penelitian yang dilakukan oleh Hutasuhut (2010). Hasil penelitian tersebut menunjukkan penerapan PBL mampu meningkatkan hasil belajar siswa. Selain itu, penerapan PBL juga dapat meningkatkan motivasi belajar siswa.Hasil penelitian lain dilakukan oleh Kamdi (2010) Penelitian tersebut menyoroti karakteristik PBL di SMK. Hasil penelitian menunjukkan terdapat tiga konfigurasi model PBL yaitu, (1) PBL yang menempatkan kerja proyek sebagai wahana pengembangan keterampilan teknikal,dan dominasi peran guru dalam proses penyelesaian kerja proyek, (2) PBL 
yang menempatkan kerja proyek sebagai wahana mendekatkanbelajar teoritik dan praktikal, kontekstual, tetapi kontrol guru dalam proses penyelesaian proyek masih cukup tinggi, (3) PBL yang menempatkan kerja proyek sebagai wahana pengintegrasian belajar teoritik-praktikal, belajar pemecahan masalah kontekstual, kolaboratif, dan pemberian otonomi yang besar kepada siswa dalam pengambilan keputusan penyelesaian kerja proyek. PBL yang ideal hendaknya menggunakan konfigurasi yang ketiga.

Hal yang esensial dari hasil penelitian tersebut adalah kecakapan yang dipersepsi siswa paling mendapat kontribusi melalui penerapan PBL di mana beberapa diantaranya yaitu,(1) kemampuan menggunakan alat-alat tertentu dalam bekerja; (2) kemampuan bekerja dengan komputer, (3) kemampuan menggunakan alat-alat dasar secara efektif, (4) bertanggung jawab terhadap kualitas produk, serta (5) kemampuan bekerja secara kooperatif. Penelitian yang di lakukan oleh Kamdi dan Hutasuhut telah mengungkapkan beberapa karakteristik PBL dan pengaruhnya terhadap motivasi serta hasil belajar, namun demikian penelitian tersebut belum dapat menggambarkan peningkatan aktivitas memanfaatkan laboratorium komputer di
SMK melalui penerapan project based learning.

Berdasarkan latar belakang masalah tersebut, penelitian ini bertujuan untuk menjawab rumusan masalah yaitu, (1) apakah terdapat perbedaan penggunaan laboratorium computer sebelum dan sesudah penerapan project based learning (PBL)? serta, (2) apakah terdapat perbedaan hasil belajar mengoperasikan aplikasi komputer akuntansi sebelum dan sesudah implementasi PBL?.

Lokasi penelitan adalah SMK Al Falah Winong kabupaten Pati propinsi Jawatengah. Salah satu fenomena menarik yang terdapat di SMK adalah rendahnya penggunaan laboratorium komputer. Padahal saat ini SMK Al Falah Winong memiliki siswa mencapai 1250 orang. Dalam upaya meningkatkan kualitas pembelajaran, khususnya program keahlian akuntansi, SMK Al Falah Winong berusaha untuk memenuhi kuantitas dan kualitas sarana prasarana khususnya laboratorium komputer. Hal itu terlihat dari peningkatan jumlah unit komputer dari 20 unit komputer pada tahun pelajaran 2014/2015 menjadi 40 unit komputer pada tahun pelajaran 2015/2016.

Penambahan jumlah tersebut ternyata tidak memberikan dampak signifikan terhadap pemakaian komputer setelah jam pembelajaran selesai. Padahal 
sekolah telah memprogramkan adanya kegiatan ekstrakurikuler yaitu accounting challenge. Selain itu, sekolah juga telah menyusun jadwal penggunaan laboratorium komputer sebagai upaya untuk memaksimalkan pemakaian laboratorium komputer.

Tabel 1.1 Jadwal Penggunaan Laboratorium komputer SMK Al Falah Winong Tahun Pelajaran 2014/2015

\begin{tabular}{|l|l|c|}
\hline No & \multicolumn{1}{|c|}{ Hari } & Jam \\
\hline 1 & Senin & $15.00-16.30$ \\
\hline 2 & Selasa & $15.00-16.30$ \\
\hline 4 & Rabu & $15.00-16.30$ \\
\hline 5 & Kamis & $15.00-16.30$ \\
\hline 6 & Jumat & $15.00-16.30$ \\
\hline 7 & Sabtu & $15.00-16.30$ \\
\hline
\end{tabular}

Sumber. Jadwal Penggunaan Laboraturium Komputer SMK Al Falah Winong T.P 2014/2015

Berdasarkan jadwal di atas dapat di lakukan analisis, bahwa apabila satu semester terdiri dari 5 bulan efektif, maka dapat disimpulkan bahwa setiap siswa memiliki kesempatan kurang lebih 20 kali untuk melakukan praktek di luar jam sekolah. Namun demikian, berdasarkan data sekunder yang di himpun, setiap siswa rata-rata hanya menggunakan laboratorium komputer tiga sampai lima kali dalam satu semester. Itu artinya, prosentase penggunaan laboraturium.
Akuntasi hanya 15\% sampai 20\%. Angka tersebut tentu relatif kecil bila di bandingkan dengan program kerja sekolah yang mentargetkan penggunaan lab. akuntasi mencapai 70\% pada tahun 2016 .

Selain penggunaan laboratorium komputer, prestasi akademik siswa akuntansi dalam lomba keterampilan siswa serta uji kompetensi kejuruan juga belum menampakkan hasil yang memuaskan. Hal itu dapat di lihat dari tabel berikut.

Tabel 1.2. Prestasi Belajar Siswa Akuntansi Pada Lomba Keterampilan Siswa Tingkat

\begin{tabular}{|l|l|l|l|}
\hline No & \multicolumn{1}{|c|}{ Tahun } & \multicolumn{1}{|c|}{$\begin{array}{c}\text { Lomba } \\
\text { Keterampilan Siswa }\end{array}$} & $\begin{array}{c}\text { Nilai rata-rata uji } \\
\text { kompetensi } \\
\text { kejuruan }\end{array}$ \\
\hline 1 & $2012 / 2013$ & Peringkat 5 & 62 \\
\hline 2 & $2013 / 2014$ & Peringkat 4 & 73 \\
\hline
\end{tabular}


\begin{tabular}{l|l|l|l|}
\hline 4 & $2014 / 2015$ & Peringkat 4 & 70 \\
\hline Sumber: Prestasi Belajar Siswa Akuntansi SMK Al Falah Winong Tahun Pelajaran
\end{tabular} 2014/2015

Pada tahun pelajaran 2012/2013

SMK Al Falah Winong menempati peringkat 5 dari 7 peserta lomba sedangkan nilai rata-rata uji kompetensi kejuruan oleh lembaga sertifikasi profesi akuntansi (LSP) hanya 62. Hasil tersebut tentu masih cukup jauh bila dibandingkan dengan kriteria ketuntasan minimal yang ditargetkan sekolah yaitu 75 . Pada tahun pelajaran selanjutnya yaitu 2013/2014, prestasi belajar baik pada lomba keterampilan siswa dan nilai rata-rata kompetensi kejuruan juga tidak banyak mengalami peningkatan. Bahkan pada tahun pelajaran 2014/2015 justru mengalami penurunan.

Upaya yang dilakukan guru komputer akuntansi untuk mengatasi permasalahan di atas adalah melalui model pembelajaran project based learning. Upaya ini telah di terapkan sejak tahun pelajaran 2016/2017. Penerapan model pembelajaran project based learning adalah melalui pemberian tugas proyek pada setiap kompetensi dasar komputer akuntansi. Melalui sistem penugasan tersebut diharapkan akan meningkatkan penggunaan laboratorium komputer demi tercapainya hasil belajar yang optimal baik bidang akademik maupun non akademik.

Penelitian dilakukan selama 2 tahun yaitu tahun pelajaran 2015/2016 dan 2016/2017. Pengumpulan data dilakukan selama dua periode yaitu tahun pelajaran 2015/2016 dan 2016/2017. Pengumpulan data dilakukan menggunakan metode dokumentasi pelaksanaan PBL melalui perangkat pembelajaran serta dokumentasi penggunaan laboratorium komputer berdasarkan data sekunder petugas laboran. Selain itu, metode dokumentasi juga digunakan untuk mendokumentasikan hasil belajar siswa melalui nilai uji kompetens kejuruan (UKK) komputer akuntansi.

\section{KAJIAN PUSTAKA}

\section{Project Based Learning}

Menurut Blumenfeld (2006) problem based learning (PBL) adalah bentuk pembelajaran yang disituasikan serta dilandasi oleh pendekatan belajar construktivistik yang meyakini bahwa siswa akan memiliki pemahaman mendalam terhadap materi ketika mereka aktif mengkonstruksikannya melalui pekerjaan serta penggunaan ide. PBL 
merupakan pendekatan menyeluruh dalam upaya mengkondisikan lingkungan belajar. bentuk pengkondisian tersebut mencakup lima kunci utama.

1. Diawali dengan pertanyaan mengenai permasalahan yang akan diselesaikan;

2. Siswa melakukan eksplorasi terhadap pertanyaan tersebut melalui partisipasi nyata dalam sebuah penyelidikan;

3. Siswa, guru dan anggota kelompok ikut serta dalam menemukan solusi permasalahan;

4. Pada saat melakukan proses penyelidikan siswa dapat memanfaatkan teknologi pembelajaran yang dapat membantunya berpartisipasi nyata diluar kemampuannya. Menurut (Novak ,2004) teknologi pembelajaran dapat mendukung siswa dalam, mengakses dan mengumpulkan informasi dan data sains, (2) menyediakan visualisasi dan alat analisis data seperti yang digunakan oleh para ilmuan, (3) mengikuti, menggabungkan serta berbagi informasi, (4) merencanakan, membangun, serta menguji model, dan (5) mengembangkan dokumentasi dalam bentuk multimedia yang menggambarkan tingkat pemahaman siswa.
5. Siswa membuat kumpulan produk sesuai dengan rumusan masalah.

(Krajcik, 2006)

Pada praktinya, pembelajaran berbasis proyek telah berhasil memperbaiki praktik pembelajaran pada pendidikan dan teknologi sehingga dimensi-dimensi kecakapan siswa mencakup academic skills, occupational skills, dan employability skill dapat berkembang secara optimal (Kamdi, 2010). Pernyataan tersebut juga didukung oleh berbagai penelitian yang menunjukkan bahwa PBL dapat meningkatkan hasil belajar, berpikir tingkat tinggi serta memperbaiki kecakapan berpikir kritis, memperbaiki kemampuan memandang situasi dari perspektif lain secara lebih baik, memberikan pemahaman mendalam terhadap materi dan bahan ajar, menumbuhkan sikap positif terhadap bidang kajian, meningkatkan interaksi positif terhadap kawan sejawat serta meningkatkan motivasi. (Johnson, 2000).

Selain berbagai peningkatan hasil belajar tersebut, secara spesifik, Thomas, (2000) mengemukakan lima peningkatan positif dari berbagai hasil penelitian tentang PBL yaitu, (1) meningkatkan prestasi belajar siswa, (2) meningkatkan kemampuan siswa dalam menyelesaikan masalah, (3) meningkatkan pemahaman 
siswa terhadap materi pelajaran, (4) meningkatkan pemahaman yang dikaitkan dengan skill khusus dan strategi yang diperkenalkan dalam proyek, sehingga laboratorium dapat digunakan sebagai lingkungan belajar yang efektif, serta (5) terjadinya perubahan positif terhadap individu dalam kelompok, serta kebiasaan bekerja.

Senada dengan itu Rais (2010) juga menunjukkan hasil yang sama di mana project based learning mampu meningkatkan prestasi akademik mahasiswa. Kamdi (2010) menambahkan bahwamodel pembelajaran berbasis proyek yang ideal adalah melalui konfigurasi menempatkan kerja proyek sebagai wahana pengintegrasian belajar teroretikpraktikal, belajar pemecahan masalah kontekstual, kolaboratif, dan pemberian otonomiyang besar kepada siswa dalam pengambilan keputusan penyelesaian kerja proyek.

\section{Laboratorium Komputer}

Pembelajaran merupakan proses interaksi antara siswa dengan guru, siswa dengan siswa dan siswa dengan lingkungan belajar. Salah satu bentuk lingkungan belajar yang ada disekolah adalah laboratorium. Dasar hukum yang memuat peraturan mengenai laboratorium sekolah adalah PP No 19 Tahun 2005 tentang standar sarana prasarana serta PP Nomor 32 Tahun 2013 tentang Perubahan atas Peraturan Pemerintah Nomor 19 Tahun 2005 Tentang Standar Nasional Pendidikan. dalam peraturan tersebut dijelaskan:

"Standar sarana dan prasarana adalah standar nasional pendidikan yang berkaitan dengan kriteria minimal tentang ruang belajar, tempat berolahraga, tempat beribadah, perpustakaan, laboratorium, bengkel kerja, tempat bermain, tempat berkreasi dan berekreasi, serta sumber belajar lain, yang diperlukan untuk menunjang proses pembelajaran, termasuk penggunaan teknologi informasi dan komunikasi”.

Lebih lanjut setiap satuan pendidikan wajib memiliki laboratorium guna menunjang aktivitas pembelajaran tidak terkecuali satuan pendidikan menengah kejuruan atau SMK. Kewajiban tersebut diatur dalam pasal 42 ayat 2 PP No 19 Tahun 2005 tentang standar Nasional Pendidikan.:

"Setiap satuan pendidikan wajib memiliki prasarana yang meliputi lahan, ruang kelas, ruang pimpinan satuan pendidikan, ruang pendidik, ruang tata usaha, ruang perpustakaan, ruang laboratorium, ruang bengkel kerja, ruang 
unit produksi, ruang kantin, instalasi daya dan jasa, tempat berolahraga, tempat beribadah, tempat bermain, tempat berkreasi, dan ruang tempat lain yang diperlukan untuk menunjang proses pembelajaran yang teratur dan berkelanjutan".

Berdasarkan PP No. 19 Tahun 2005 Tentang Standar Nasional Pendidikan dapat diketahui bahwa fungsi laboratorium adalah menunjang proses pembelajaran serta penggunaan teknologi informasi dan komunikasi.

Bagi satuan pendidikan menengah kejuruan atau SMK, laboratorium memiliki peranan sangat penting. Hal itu disebabkan karena SMK memiliki jenis mata pelajaran produktif yang menekankan pada kemampuan psikomotorik siswa dalam mempraktekan kompetensi tertentu sehingga pembelajaran tidak cukup dilaksanakan di kelas namun harus dilanjutkan ke laboratorium.

Salah satu kompetensi keahlian yang membutuhkan laboratorium akuntansi adalah bisnis dan manajemen. Pada program keahlian akuntansi, laboratorium dibutuhkan guna menunjang aktivitas pembelajaran yang berkaitan dengan dua kompetensi dasar yaitu, mengoperasikan paket program pengolah angka/ spreadsheet, serta mengoperasikan aplikasi komputer akuntansi.

Komputer merupakan salah satu perangkat penting dalam lingkungan belajar di sekolah. Pada banyak satuan pendidikan, di mana komputer digunakan laboratorium komputer memegang peranan penting. Menurut kajian teoritis, penggunaan laboratorium komputer dapat diklasifikasikan menjadi dua yaitu laboratorium formal dan laboratorium terbuka (Lin, 1996). Laboratorium formal direncanakan dengan cara yang sama seperti saat pembelajaran dan seminar dengan tugas yang spesifik perlu dikerjakan oleh siswa.Laboratorium ini pada umumnya dikelola oleh guru. Disisi lain, laboratorium terbuka mengijinkan siswa untuk data dan pergi sesukahati. Penggunaan laboratorium ini biasanya dilakukan dengan bantuan teknis dari petugas laboratorium.

Berkaitan dengan hasil belajar siswa, penelitian (Fisher, 1999) menunjukkan bahwa laboratorium komputer memiliki hubunganyang signifikan dengan sikap siswa terhadap pembelajaran. Hasil penelitian juga menunjukkan adanya hubungan langsung antara laboratorium komputer dan prestasi melalui sikap yang ditunjukkan dalam pembelajaran. Hasil penelitian juga menunjukkan bahwa pembelajaran yang dilakukan dengan 
melibatkan laboratorium komputer berpengaruh positif terhadap kegembiraan siswa dalam belajar. Kegembiraan tersebut membawa dampak pada penurunan tingkat kecemasan sehingga hasil belajar yang dicapai dapat lebih baik.

\section{Hasil Belajar Siswa}

Hasil belajar merupakan perubahan tingkah laku baik kognitif, afektif maupun psikomotorik. Pernyataan tersebut sesuai dengan apa yang disampaian Nana (2013) yang mendefinisikan hasil belajar siswa pada hakikatnya adalah perubahan tingkah laku sebagai hasil belajar dalam pengertian yang lebih luas mencakup bidang kognitif, afektif, dan psikomotorik. Gambaran mengenai hasil belajar bidang kognitif sering kali diperoleh dari skor tes formatif maupun tes sumati sedangkan hasil belajar di bidang psikomotorik, seringkali diperoleh melalui pengamatan (observasi) kemampuan siswa dalam menggunakan pengetahuannya untuk memecahkan permasalahan atau mempraktekkan keterampilan tertentu. Pengamatan terhadap kemampuan praktek tersebut di SMK sering disebut dengan ujian praktik.

Salah satu hasil belajar yang harus dimiliki oleh siswa SMK adalah kemampuan mengoperasikan aplikasi komputer akuntansi. Kompetensi tersebut merupakan salah satu kompetensi yang dimuat dalam Keputusan Menteri Tenaga Kerja dan Transmigrasi Republik Indonesia Nomor. 43 Tahun 2008 TentangPenetapan Standar Kompetensi Kerja Nasioanal Indonesia Sektor Real Estate, Usaha Persewaan dan Jasa Perusahaan Sub Sektor Jasa Perusahaan Lainnya Bidang Jasa Akuntansi dan Perpajakan Sub Bidang Teknisi Akuntansi. Metode asesmen yang dilakukan sekolah untuk memperoleh gambaran mengenai hasil belajar mengenai kompetensi tersebut adalah melalui uji kompetensi yang melibatkan fihak eksternal seperti kantor akuntansi publik.

Penguasaan terhadap kompetensi tersebut membutuhkan peranan teknologi komputer. Namun demikian, sekolah seringkali dihadapkan pada masalah perbedaan individu khususnya perbedaan sosial ekonomi. (Levin, 1990) mengemukakan lima tingkatan dalam struktur sosialekonomi yaitu, (1) upper, (2) upper middle, (3) lower middle, (4) upper working, (5) lower working. Perbedaan tersebut membawa dampak besar terhadap perubahan tingkahlaku disebabkan karena adanya perbedaan pengalaman yang diperoleh siswa. Tanpa adanya masalah perceraian (masalah internal keluarga), siswa yang berasal dari keluarga 
menengah keatas, seringkali mendapatkan pengalaman yang lebih baik baik ditinjau dari saranya prasarana. Menurut Slavin (2005) salah satu strategi untuk mengatasi permasalahan tersebut adalah melalui penambahan jam praktik untuk kompetensi tertentu.

Upaya yang dikemukakan oleh Slavin dapat diwujudkan melalui penambahan jam praktik diluar jam sekolah. Artinya, siswa dapat diarahkan untuk menggunakan laboratorium komputer setelah jam pulang sekolah. Aktivitas tersebut tentusaja bertujuan untuk meningkatkan hasil belajar terutama berkaitan dengan kemampuan mengoperasikan aplikasi komputer akuntansi. Berdasarkan landasan teori yang diuraikan di atas dipotesis dalam penelitian ini dirumuskan sebagai berikut.

1. Terdapat perbedaan aktivitas menggunakan laboratorium komputer sebelum dan sesudah penerapan PBL. Secara matematis dapat ditulis sebagai berikut.

$H_{0}=\mu_{0.1} \geq \mu_{0.2}$

$H_{1}=\mu_{1.1}<\mu_{1.2}$

2. Terdapat perbedaan hasil belajar siswa pada kompetensi mengoperasikan aplikasi komputer akuntansi sebelum dan sesudah penerapan PBL. Secara Tabel 1.3 Populasi dan Sampel Penelitian matematis dapat ditulis sebagai berikut.

$$
\begin{aligned}
& H_{2.0}=\mu_{2.0 .1} \geq \mu_{2.0 .2} \\
& H_{2.1}=\mu_{2.1 .1}<\mu_{2.1 .2}
\end{aligned}
$$

Di mana :

$\mu_{0.1}=$ Penggunaan laboratorium komputer sebelum penerapan PBL.

$\mu_{0.2}=$ Penggunaan laboratorium komputer sesudah penerapan PBL.

$\mu_{2.0 .1}=$ Hasil belajar sebelum penerapan PBL.

$\mu_{2.0 .2}=$ Hasil belajar setelah penerapan PBL.

\section{METODE PENELITIAN}

Penelitian ini menggunakan metode kuantitatif. Jenis penelitian ini adalah causal comparative research di mana penelitian di tujukan untuk mengeksplorasi variabel dampak implementasi PBL terhadap aktivitas menggunakan laboratorium komputer serta hasil belajar komputer akuntansi pada uji kompetensi.

Populasi penelitian ini adalah seluruh siswa kelas XI dan XII program keahlian akuntansi SMK Al Falah Winong. Populasi dibagi menjadi dua angkatan yaitu tahun pelajaran 2015/2016 serta 2016/2017. Jumlah populasi disajikan dapat peneliti sajikan dalam tabel berikut.

\begin{tabular}{|l|c|c|c|c|}
\hline No & Tahun & Kelas & Jumlah & Jumlah \\
\hline
\end{tabular}




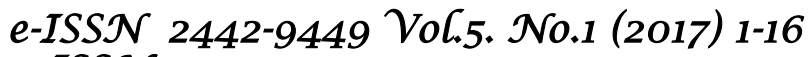

p-ISSN 2337-4721

\begin{tabular}{|c|l|l|l|l|}
\hline & Pelajaran & & Siswa & Sampel \\
\hline \multirow{4}{*}{1} & \multirow{3}{*}{$2015 / 2016$} & XI akuntansi 1 & 39 & 20 \\
\cline { 4 - 5 } & & XI akuntansi 2 & 38 & 19 \\
\cline { 3 - 5 } & & XII akuntansi 1 & 48 & 18 \\
\cline { 3 - 5 } 2 & XII akuntansi 2 & 0 & 0 \\
\hline \multirow{4}{*}{$2016 / 2017$} & XI akuntansi 1 & 43 & 22 \\
\cline { 4 - 5 } & & XI akuntansi 2 & 42 & 21 \\
\cline { 3 - 5 } & & XII akuntansi 1 & 39 & 20 \\
\cline { 3 - 5 } & & XII akuntansi 2 & 38 & 19 \\
\hline
\end{tabular}

Sumber: Populasi dan Sampel Penelitian SMK Al Falah Winong Tahun Pelajaran $2014 / 201$

Pengamatan terhadap penggunaan laboratorium komputer akan dilakukan terhadap kelas XI akuntansi 1 dan kelas XI akuntansi 2 pada tahun pelajaran 2015/2016di mana pada saat itu belum dilaksanakan PBL. Selanjutnya, pengamatan akan dilanjutkan ketika mereka telah beranjak kekelas XII akuntansi 1 dan XII akuntansi 2 pada tahun pelajaran 2016/2017. Metode pengambilan sampel menggunakan proportiona test ratified random sampling (Sugiyono, 2016). Berdasarkan tabel 1.3 dapat diketahui jumlah populasi adalah sebebasar 77. Berdasarkan jumlah tersebut perhitungan sampel adalah (39/77) x $39=$ 19,7 (dibulatkan menjadi 20 orang) untuk kelas XI akuntansi 1 pada tahun pelajaran 2015/2016 dan kelas XII akuntansi 1 pada tahun pelajaran 2015/2016. Sedangkan perhitungan sampel berikutnya adalah (38/77) x $38=18,7$ (dibulatkan 19 orang).
Pengamatan terhadap hasil belajar siswa SMK program keahlian akuntansi dilakukan dengan membandingkan data hasil belajar XII akuntansi 1 pada tahun pelajaran 2015/2016 serta kelas XII akuntansi 1 dan 2 pada tahun pelajaran 2016/2017. Berdasarkan tabel 3.1 dapat diketahui jumlah populasi adalah sebebasar 125. Berdasarkan jumlah tersebut perhitungan sampel adalah $(48 / 125)$ x $48=18,4$ (dibulatkan menjadi 18 orang) untuk kelas XII akuntansi 1 pada tahun pelajaran 2015/2016. Sedangkan perhitungan sampel berikutnya adalah $(39 / 125) \times 39=12,1$ (dibulatkan 12 orang) untuk kelas XII akuntansi 1, dan (38/125) x $38=11,5$ (dibulatkan 12 orang) untuk kelas XII akuntansi 2 pada tahun pelajaran 2015/2016.

Teknik analisis data menggunakan uji $t$ menggunakan program SPSS 20. Data yang di analisis adalah perbandingan rerata penggunaan laboratorium komputer siswa 
kelas Akuntansi 1 dan siswa kelas Akuntansi 2 pada tahun pelajaran 2015/2016 ketika mereka masih kelas XI dan 2016/2017 ketika mereka kelas XII. Sedangkan analisis berikutnya dilakukan dengan membandingkan rerata hasil uji kompetensi mengoperasikan aplikasi komputer akuntansi kelas XII akuntansi 1 pada tahun pelajaran 2015/2016 dan kelas XII akuntansi 1 dan 2 pada tahun $2016 / 2017$.

\section{PEMBAHASAN HASIL PENELITIAN}

Tabel. 1.4 Group Statistics

\begin{tabular}{|cc|c|c|c|c|}
\hline \multicolumn{2}{|c|}{$\begin{array}{c}\text { Project Based } \\
\text { Learning }\end{array}$} & $\mathrm{N}$ & Mean & $\begin{array}{c}\text { Std. } \\
\text { Deviation }\end{array}$ & $\begin{array}{c}\text { Std. } \\
\text { Error } \\
\text { Mean }\end{array}$ \\
\hline Penggunaan & 2.00 & 39 & 8.1795 & 1.23271 & .19739 \\
Laboratorium & 1.00 & 40 & 6.1250 & 1.65153 & .26113 \\
\hline
\end{tabular}

Sumber : Data primer diolah menggunakan program SPSS 20

Rata-rata sampel $(\bar{X})$ tabel 1.2 menunjukan terdapat selisih yang cukup besar yaitu 2.0545 atau sebesar 14\%. Perbedaan tersebut selanjutnya dianalisis
Data yang diolah dalam penelitian ini adalah data primer yang dikumpulkan menggunakan lembar observasi. Hasil pengolahan data ditunjukkan pada tabel berikut.

Tabel 1.5 Independent Samples Test

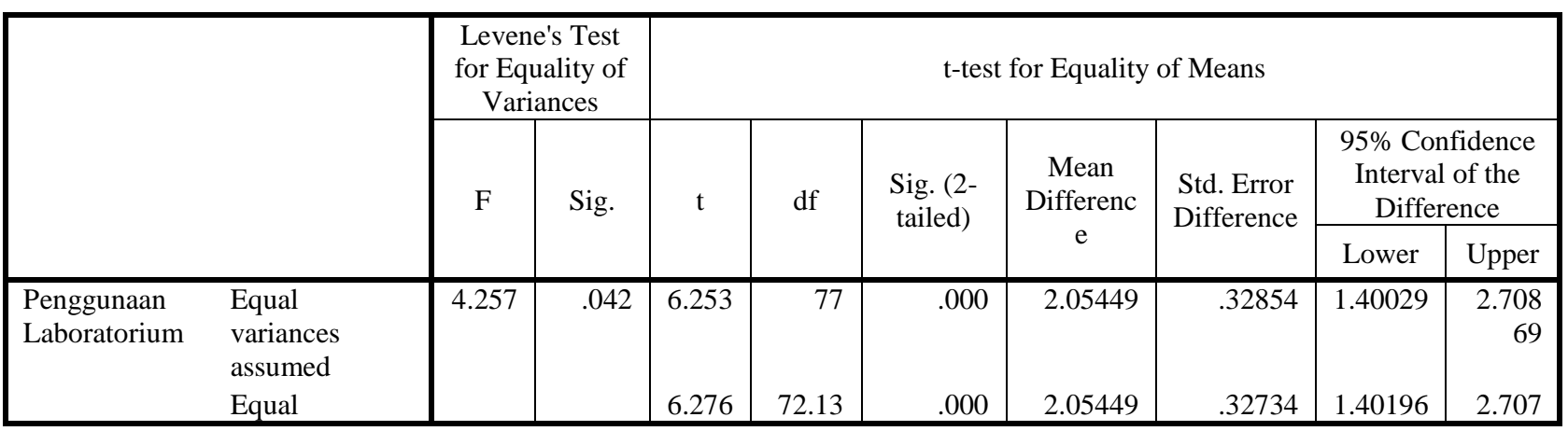




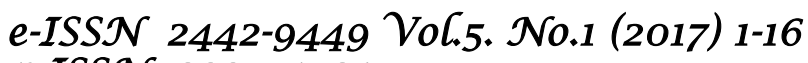

$p$-ISSN 2337-4721

variances not assumed

Sumber : Data primer diolah menggunakan program SPSS 20

Tabel 1.5 menunjukkan bahwa diambil keputusan bahwa $H_{0}$ ditolak dan terdapat perbedaan yang signifikan antara $H_{1}$ diterima.

penggunaan laboratorium komputer sebelum dan sesudah adanya PBL di SMK Al Falah Winong.Hal itu ditunjukkan dari nilai $t_{\text {hitung }}$ sebesar 6.253 dan $t_{\text {tabel }}$ sebesar 1.99dengan taraf signifikansi sebesar 0.04 atau lebih kecil dari pada 0.05 yang berarti $t_{\text {hitung }} \geq t_{\text {tabel }}$ dan signifikan pada 0.05 sehingga dapat

Tabel. 1.6 Group Statistics

\begin{tabular}{|l|c|c|r|c|}
\hline $\begin{array}{l}\text { Project } \\
\text { Based } \\
\text { Learning }\end{array}$ & $\mathrm{N}$ & Mean & $\begin{array}{c}\text { Std. } \\
\text { Deviation }\end{array}$ & $\begin{array}{c}\text { Std. } \\
\text { Error } \\
\text { Mean }\end{array}$ \\
\hline Hasil 2.00 & 40 & 74.8000 & 6.65717 & 1.05259 \\
UKK r 1.00 & 18 & 66.1667 & 10.55657 & 2.48821 \\
\hline
\end{tabular}

Sumber : Data primer diolah menggunakan program SPSS 20

Rata-rata sampel $(\bar{X})$ tabel 1.6 tersebut selanjutnya dianalisis kembali menunjukan terdapat selisih yang cukup menggunakan uji $t$ dua sampel untuk besar antara hasil uji kompetensi kejuruan mengetahui perbedaannya secara statistik. (UKK) sesudah PBL dengan sebelum PBL Hasil tersebut di tampilkan dalam tabel yaitu 8.63 atau sebesar 6\%. Perbedaan berikut.

Tabel 1.7 Independent Samples Test

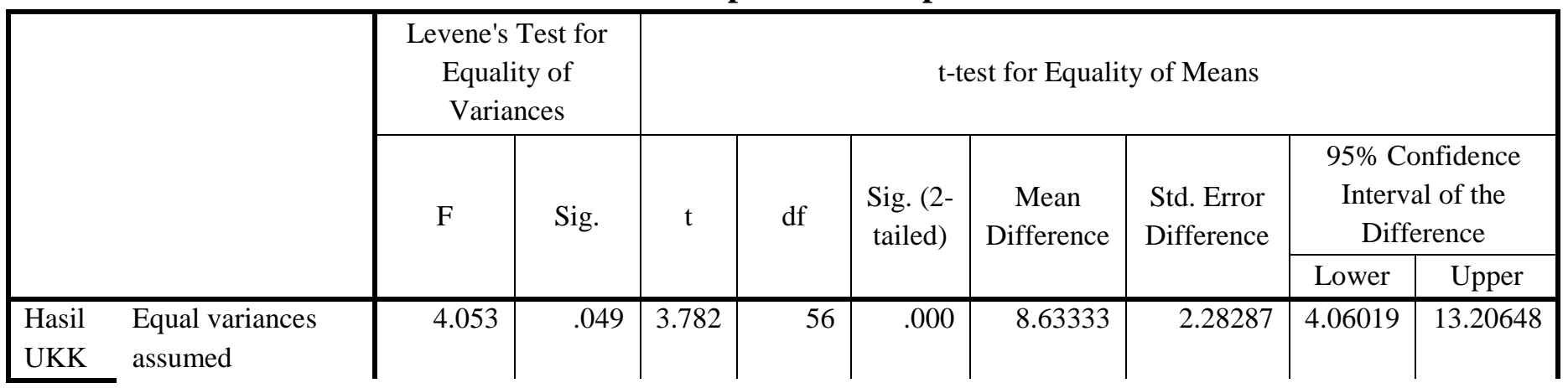


Equal variances

not assumed

Sumber : Data primer diolah menggunakan program SPSS 20

Tabel 3.5menunjukkan bahwa terdapat perbedaan yang signifikan antara penggunaan laboratorium komputer sebelum dan sesudah adanya PBL di SMK Al Falah Winong. Hal itu ditunjukkan dari nilai $t_{\text {hitung }}$ sebesar 3.782 dan $t_{\text {tabel }}$ sebesar 2.003 dengan taraf signifikansi sebesar 0.04 atau lebih kecil dari pada 0.05 yang berarti $t_{\text {hitung }} \geq t_{\text {tabel }}$ dan signifikan pada 0.05 sehingga dapat diambil keputusan bahwa $H_{0}$ ditolak dan $H_{1}$ diterima.

Hasil analisis di atas membuktikan bahwa PBL mampu memberikan efek meningkatnya aktivitas menggunakan laboratorium komputer. PBL juga mampu meningkatkan hasil belajar siswa SMK program keahlian akuntansi khususnya pada mengoperasikan aplikasi komputer akuntansi. Kesimpulan ini sesuai dengan teori tentang PBL yang menjelaskan bahwa melalui PBL siswa dapat memanfaatkan teknologi pembelajaran yang dapat membantunya berpartisipasi nyata diluar kemampuannya. Salah satu teknologi yang dapat digunakan dalam hal ini adalah komputer yang ada di laboratorium komputer.

Pemanfaatan teknologi tersebut dilator belakangi oleh adanya permasalahan yang harus diselesaikan siswa untuk menguasai kompetensi mengoperasikan aplikasi komputer akuntansi. Melalui permasalahan yang disajikan dalam bentuk proyek, secara tidak langsung guru memberikan stimulus kepada siswa untuk melakukan sesuatu untuk menyelesaikannya. Bagi siswa yang memiliki personal computer, mungkin mereka dapat menyelesaikan permasalahan menggunakan sarana prasarana yang dimiliki. Namun demikian, bagi mereka yang tidak memiliki fasilitas tersebut, mau tidak mau mereka akan menggunakan laboratorium komputer yang ada disekolah sehingga frekwensi penggunaan laboratorium komputer pun mengalami peningkatan.

Hasil penelitian juga relevan dengan hasil penelitian terdahulu di mana PBL mampu meningkatkan beberapa hal seperti yang dikemukakan oleh Thomas, (2000) dan Rais (2010) yaitu, (1) meningkatkan prestasi belajar siswa, (2) meningkatkan kemampuan siswa dalam menyelesaikan masalah, (3) meningkatkan pemahaman siswa terhadap materi pelajaran, (4) meningkatkan pemahaman yang dikaitkan dengan skill khusus dan strategi yang diperkenalkan dalam proyek, sehingga laboratorium dapat digunakan sebagai lingkungan belajar yang efektif, serta (5) 
terjadinya perubahan positif terhadap individu dalam kelompok, serta kebiasaan bekerja.

\section{KESIMPULAN DAN SARAN}

Hasil penelitian ini memberikan kesimpulan sebagai berikut.

1. Penerapan PBL mampu meningkatan aktivitas menggunakan laboratorium komputer. Hal itu dibuktikan dengan hasil analisis data yang menunjukkan nilai $t_{\text {hitung }}$ sebesar 6.253 dan $t_{\text {tabel }}$ sebesar 1.99 dengan taraf signifikansi sebesar 0.04 atau lebih kecil dari pada 0.05 yang berarti $t_{\text {hitung }} \geq t_{\text {tabel }}$. Selain itu, rata-rata sampel $(\bar{X})$ sebelum penerapan dan sesudah penerapan PBL menunjukan terdapat selisih yang cukup besar yaitu 2.0545 atau sebesar $14 \%$.

2. Penerapan PBL juga mampu meningkatkan hasil belajar siswa khussunya pada kompetensi mengoperasikan aplikasi komputer akuntansi. Hal itu ditunjukkan dari nilai $t_{\text {hitung }}$ sebesar 3.782 dan $t_{\text {tabel }}$ sebesar 2.003 dengan taraf signifikansi sebesar 0.04 atau lebih kecil dari pada 0.05 yang berarti $t_{\text {hitung }} \geq t_{\text {tabel }}$ dan signifikan pada 0.05 . Selain itu, ratarata sampel $(\bar{X})$ tabel menunjukan terdapat selisih yang cukup besar antara hasil uji kompetensi kejuruan (UKK) sesudah PBL dengan sebelum PBL yaitu 8.63 atau sebesar 6\%.

\section{DAFTAR PUSTAKA}

Hutasuhut, Saidun. 2010. Implementasi Pembelajaran Berbasis Proyek (Project Based Learning) untuk Meningkatkan Frekwensi dan Hasil Belajar Mata Kuliah Pengantar Ekonomi Pembangunan Pada Jurusan Manajemen FE UNIMED. Pekbis Jurnal, Vol. 2, No. 1, 196-207

Johnson, D., Johnson, R.\& Stanne, M.E. 2000.Cooperative Learning Methods: A Meta-Analysis. http://www.clcrc.com/pages/clmethods diakses 23/11/2016

Kamdi. Waras. 2010. Implementasi Project-Based Learning di Sekolah Menengah Kejuruan. Jurnal Pendidikan dan Pembelajaran, FT Jurusan Pendidikan Teknik Mesin. Vol. 17, No. 1. April 2010

Krajcik, J., Blumenfeld, P. C. 2006. The Cambridge Handbook of the Learning Sciences.R. Keith Sawyer (ed). Cambridge University Press

Levin, M.E., \& Levin, J.R. 1990. Scientific mnemonics: Methods for maximizing more than memory. American Educational Researh Journal; 27, 301-321

Keputusan Menteri Tenaga Kerja dan Transmigrasi Republik Indonesia Nomor. 43 Tahun 2008 Tentang Penetapan Standar Kompetensi Kerja Nasioanal Indonesia 
Lin, J.M.C., Wu, C. C., \& Chiou, G, F 1996. Critical Concepts in the development of Courseware for CS clossed Laboratories (Special Issue: Integrating Technology into Computer Science Education). SIGCSE Bulletin, 28, 14-19.

Rais. M. 2010. Model Project BasedLearning Sebagai Upaya Meningkatkan Prestasi Akademik Mahasiswa. Jurnal Pendidikan dan Pengajaran, Jilid 43. Nomor 3, Oktober 2010. Hlm. 246-252

Sudjana, Nana. 2013. Penilaian Hasil Proses Belajar Mengajar. Bandung: PT.Remaja Rosdakarya.

Newbe, M. \& Fisher, D. 1999. A Model of The Relationship Between University Computer Laboratory Environment and Student Outcomes. Learning Environment Research 3: 51-66, 2000. Kluwer Academic Publishers.

Novak, A., \& Krajcik, J. S. 2004. Using Learning Technologies To Support Inquiry In Middle School Science. In L. Flick \& N. Lederman (Eds.), Scientific inquiry and nature of science: Implications for teaching, learning, and teacher education (pp. 75-102). The Netherlands: Kluwer Publishers.

Peraturan Pemerintah Nomor 19 Tahun 2005 Tentang Standar Nasional Pendidikan.

Slavin.R, E. 2005. Educational Psychology_ Theory and Practice (8th Edition)-Allyn \& Bacon.

Sugiyono. 2016. Metode Penelitian Kuantitatif, Kualitatif dan $R \& D$. Bandung: ALFABETA.

Thomas, John. W. 2000. Review of Research on Project Based-Based
Learning. California : The Autodesk Foundation 111 McInnis Parkway San Rafael.

Undang-undang Nomor 20 Tahun 2003

Tentang Sistem Pendidikan Nasional. 